\title{
Polycations. XXIV. Approaches to Polycationic Alternatives to Antibiotics
}

Authors:

Robert Engel ${ }^{1}$

Karin Melkonian $^{2}$

JaimeLee Iolani Rizzo ${ }^{3}$

Daniel Ambinder ${ }^{1}$

Laura Friedman ${ }^{1}$

1 Department of Chemistry and Biochemistry, Queens College of CUNY, 65-30 Kissena Boulevard, Flushing, NY 11367 USA

2 Department of Biology, Long island University, C.W. Post Campus, Greenvale, NY 11548 USA

3 Department of Chemistry and Physical Sciences, Pace University, One Pace Plaza, New York, NY 10038 USA

\section{Correspondence address:}

E-mail: Robert.Engel@qc.cuny.edu

\begin{abstract}
Efforts toward the development of polycationic lipid materials as alternative approaches for the control of pathogenic bacteria continue. While most prior efforts have been directed toward preventing bacterial infections, the direction is now turned toward destruction of bacteria that have already infected an organism. The use of cationic lipids with multiple sites of interaction without the opportunity for development of resistance is sought. Herein are described several carbohydrate scaffolding systems for the covalent attachment of cationic lipids to provide clusters of sites capable of disrupting the pathogenic bacterial cells. Studies with $S$. aureus and E. coli are reported.
\end{abstract}



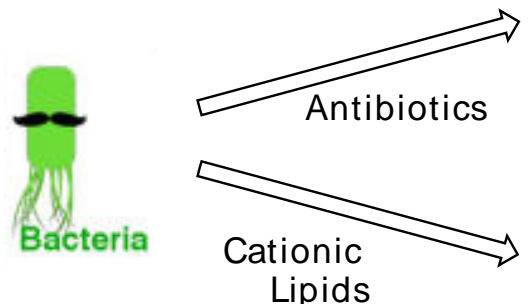

Lipids

\section{INTRODUCTION}

The normal evolution of bacterial species allowing them to thrive in even exceedingly hostile environments has become a significant difficulty for human and animal health. ${ }^{1-5}$ The evolution of bacterial species that has allowed them to become resistant to classical antibiotics is seen as a major threat to the establishment and continuation of satisfactory treatment for human and animal infectious diseases. ${ }^{6-8}$

Prior efforts of our laboratory and those of our collaborators have been concerned primarily with the prevention of transmission of pathogenic bacteria. ${ }^{9-19}$ Our approach to this end has been a novel method involving the covalent attachment of a series of cationic lipids to a variety of surfaces, particularly fabrics. Fabrics including cotton, silk, and wool have been modified using this technique, rendering those materials antibacterial and antifungal. In these efforts, cationic lipids have been bound covalently through a quaternary nitrogen site to the surface using primary hydroxyl sites there that had been activated for formation of the quaternary ammonium site by a nucleophilic substitution reaction. In this way, the cationic lipids have been organized to overcome the entropic problem of the random dispersal through a solution that provides the optimal direction for the lipid portion to interact with the wall of the bacterial cell, ultimately causing the wall of the cell to be pierced resulting in the death of the cell.

On such a surface with a high percentage of the available surface sites so activated, any impinging bacterial cell will come into contact with a large number of such cationic lipid sites, properly organized, and will readily be destroyed. For cationic lipids simply moving about in solution with bacterial cells nearby, an unreasonably high concentration is required for destruction of the cells in sufficient quantity to prevent disease. Certainly, such individual cationic lipids in solution would not be suitable candidates for pharmaceutical application in the treatment of bacterial infection.

However, there exists the possibility that cationic lipids could serve in the capacity as antibacterial pharmaceuticals. Structures could be designed such that a single soluble scaffold unit could supply sufficient cationic lipid sites for sufficient piercing of a bacterial wall. Further, the scaffold could be normally degraded after antibacterial action and it could be removed from the treated organism within a reasonable period of time after completing its antibacterial mission. To this end we have designed several series of scaffoldings on which multiple cationic lipid units could be assembled, and which would reasonably be anticipated to undergo normal degradation themselves, becoming harmless and exuded from the organism after action. One of these 
has been described recently involving a PAMAM dendrimer scaffolding. ${ }^{9}$ In this report we consider several other scaffoldings along with our initial results in evaluating their efficacy.

\section{RATIONALE}

In a rational design approach toward construction of an antibacterial using the concept of cationic lipids piercing the wall of bacterial cells, several aspects need to be considered. The first of these is that a sufficient number of cationic lipid units need to be located within a relatively small region of space to provide effective action against the bacterial wall, and further, these must be oriented properly to provide simultaneous action of the cationic lipid units. Potential candidates for such scaffolding can be found with particular carbohydrate related systems, as well as some other designs.

The cyclodextrins constitute a carbohydrate related system of particular interest wherein a series (six, seven, or eight, depending on the cyclodextrin used $-\alpha-, \beta-$, or $\gamma-$ ) of cationic lipids can be attached, all aligned with the cationic portion attached to the cyclodextrin and the lipid chains pendant, located within a small, circular region. A cartoon of such a cyclodextrin (shown as a hollow, trapezoidal torus, with the cationic lipids attached through the 6'carbon sites at the top of the torus) is shown in Figure 1.

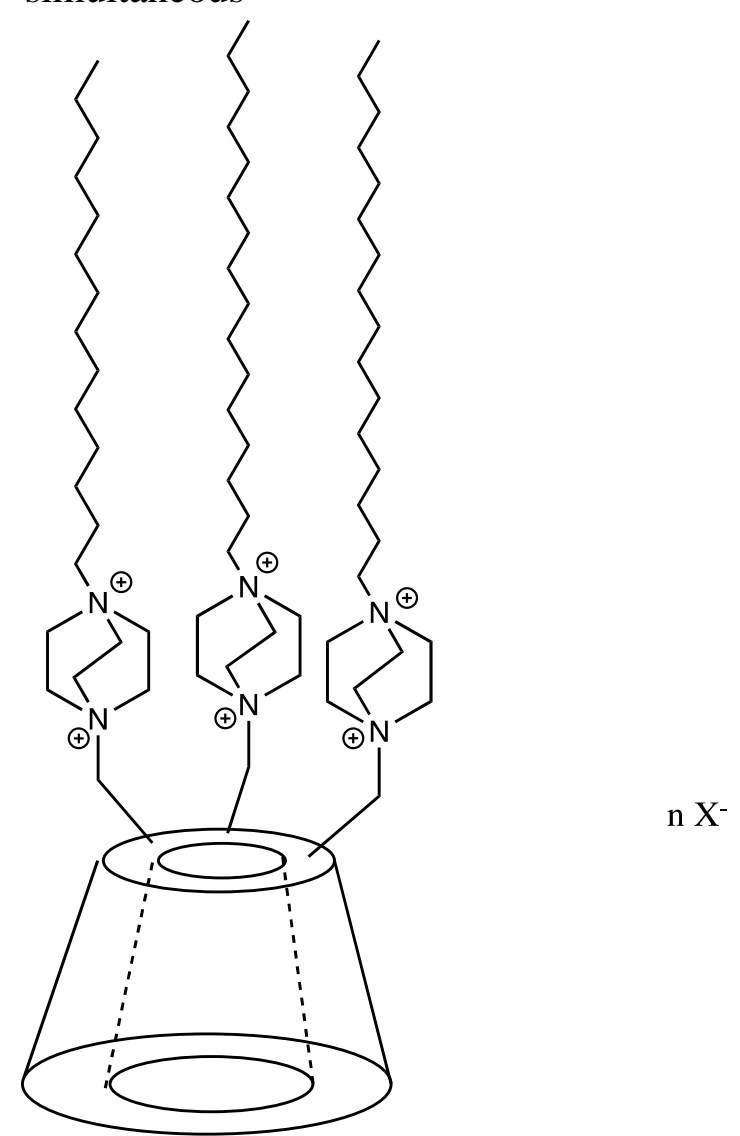

Figure 1 - Cartoon of a cyclodextrin (as a trapezoidal, hollow torus) with cationic lipid chains attached through the 6'-positions at the top of the torus (only three such linages are shown, for clarity - the actual number depends on the cyclodextrin used, $\alpha-, \beta-$, or $\gamma-$ ). Lipid chains are shown as being aligned with each other as anticipated in aqueous medium wherein they would be expected to preferentially associate with each other rather than be dispersed in the aqueous medium. 
In such a system, an organized approach for interaction with the bacterial wall could be expected, with relatively rapid degradation of the glycosidic linkages and elimination of the structurally simple monosaccharides linked to individual cationic lipid units eliminated from the host organism.

In a related manner, one could consider soluble starch systems as scaffolding to which cationic lipids could be attached. While more dispersed than the cyclodextrins, such soluble starch scaffoldings could provide a greater number of cationic lipid units in a relatively small space, albeit not in such a regular pattern, but with relative ease of degradation in the organism to form highly dispersed cationic lipids with a monosaccharide head group. The general structure is illustrated in Figure 2.

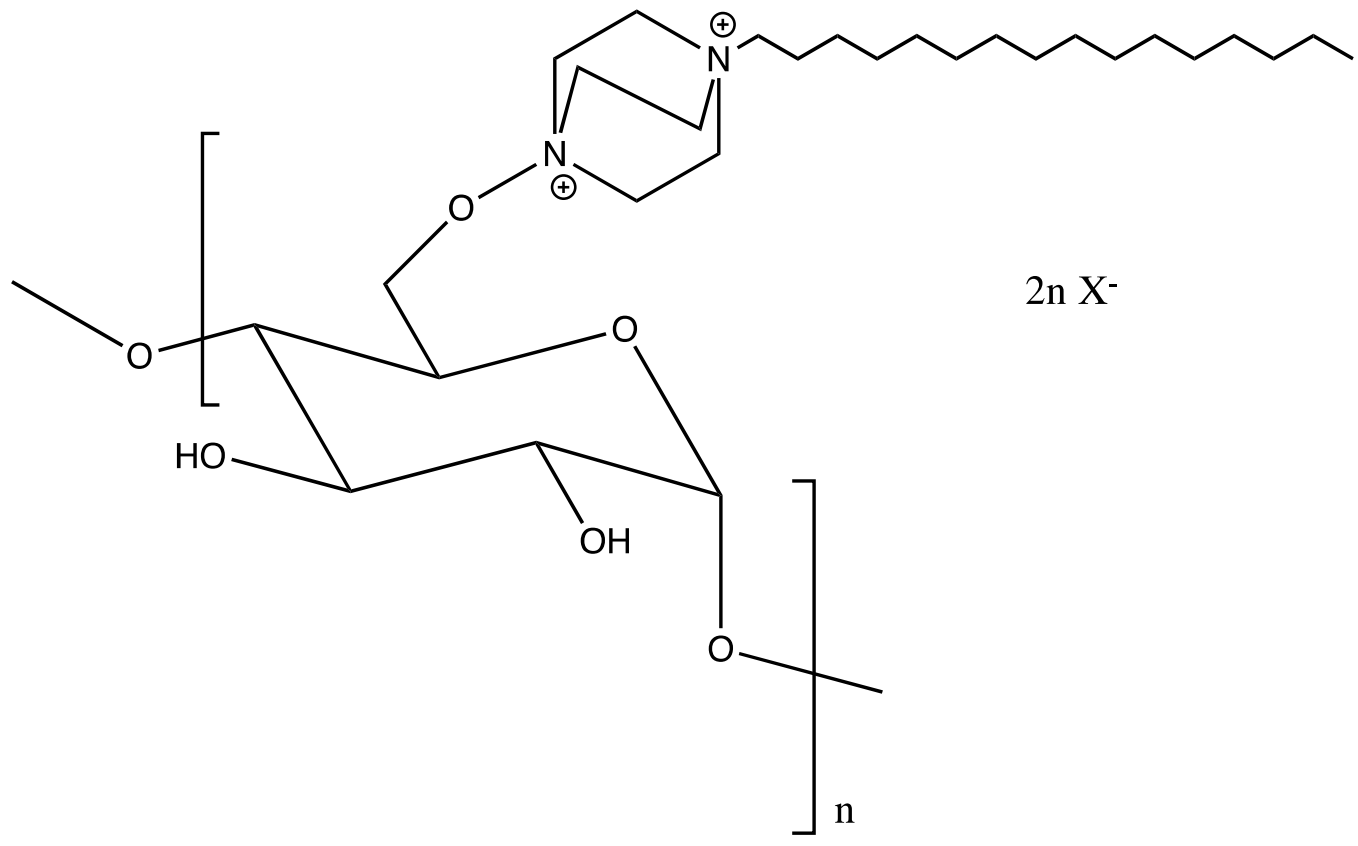

Figure 2 - Structure of a unit of soluble starch to which a cationic lipid unit at the 6'-carbon site has been attached. With this structure a single molecule containing multiple cationic lipid units can be provided to bacterial cells, and can readily be degraded to individual cationic lipids with a monosaccharide head group.

An alternative to these glycosidic scaffolds is provided by simple reduced carbohydrate molecules that can be modified readily for attachment of cationic lipid units. A simple example of such systems is mannitol, for which attachment of cationic lipid units at the terminal carbon sites is easily accomplished. An example of such a system is shown in Figure 3. 

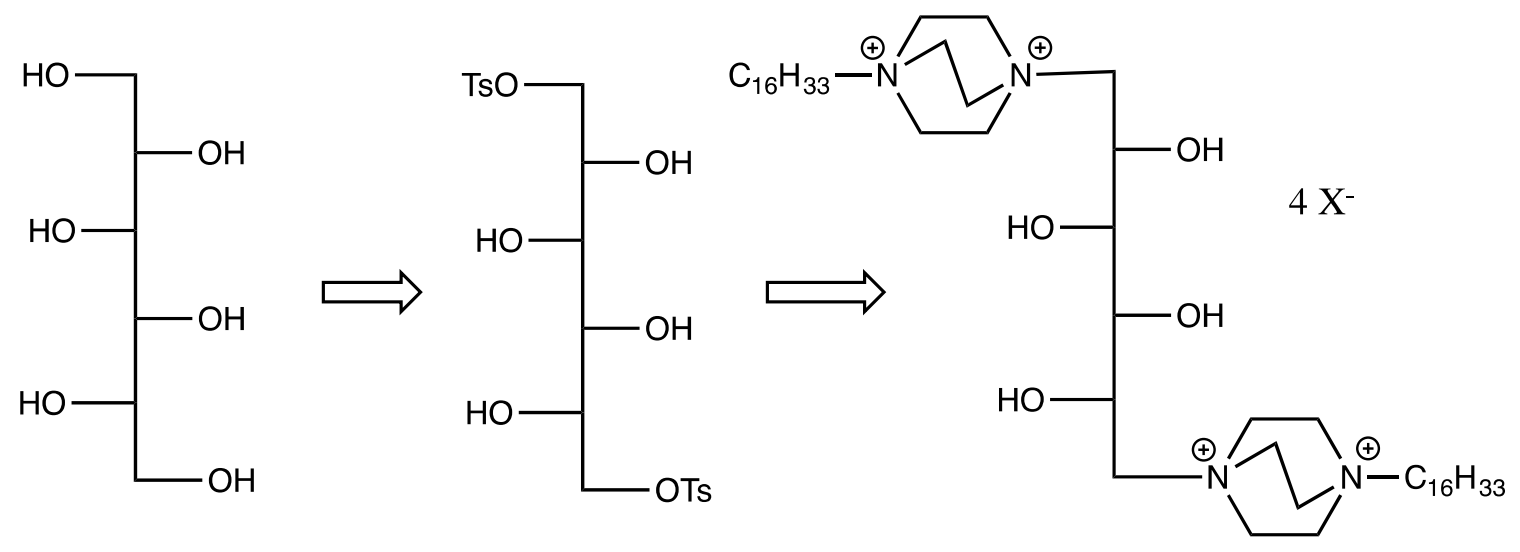

Figure 3 - Structure of a reduced carbohydrate, modified for the attachment of two cationic lipid units.

In the present work, we report the synthesis and investigation of several polycationic lipid derivatives of carbohydrate scaffoldings that hold promise as potential antibacterial agents without the common risk of evolving to resistant strains that is associated with antibiotic agents. Several types of cationic lipid agents derived from carbohydrates bearing scaffoldings related to these systems have previously been reported from our laboratory. ${ }^{20}$
3. MATERIALS SYNTHESIZED FOR INVESTIGATION

3.1 A MONOSUBSTITUTED CARBOHYDRATE CATIONIC LIPID METHYL 6-DEOXY-6- $\{1$ ', 4'DIAZONIA-4'-TETRADECYL [2.2.2]BICYCLOOCTYL\}- $\alpha$-DGLUCOPYRANOSIDE BROMIDE TOSYLATE (I)

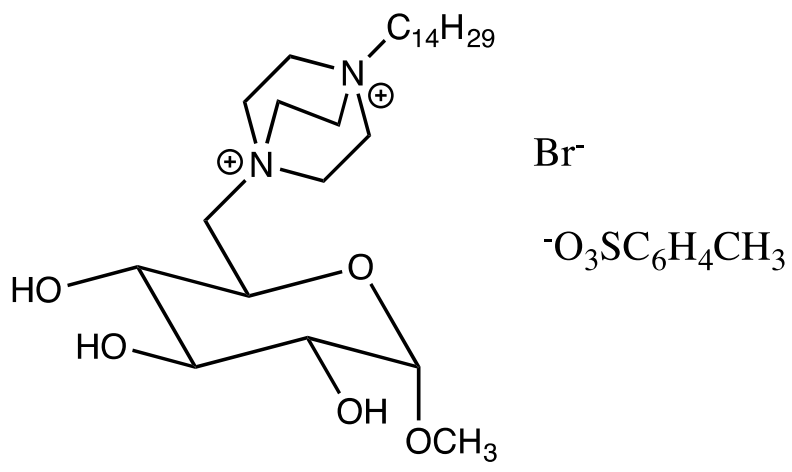

I

The material (I) was synthesized and investigated as a reference system bearing a cationic lipid functionality associated with a carbohydrate scaffolding. The parent methyl $\alpha$-D-glucopyranoside was tosylated using sodium bicarbonate and $p$-toluenesulfonyl chloride specifically at the primary 6- position hydroxyl group followed by displacement of the $p$-tosylate group using the parent lipid 4-tetradecyl-1-aza-4azoniabicyclo[2.2.2] octyl chloride. Further details regarding this material are noted in the Experimental section. 
Investigations of I with Staphalococcus aureus and Escherichia coli exhibited values for MBC of $1274 \mu \mathrm{M}$ and $254800 \mu \mathrm{M}$ respectively, with MIC of 318.5 $\mu \mathrm{M}$ and $1275 \mu \mathrm{M}$ respectively. While active, these values are relatively high and are indicative of the requirement for a highly unfavorable entropy factor associated with a lack of concerted action of the cationic lipid sites of the agent on individual bacteria.
3.2 A TETRASUBSTITUTED CATIONIC LIPID GLUCOSE DERIVATIVE (II)

The material II (as the octachloride salt) was synthesized starting with methyl Dglucopyranoside taken in reaction with 4chlorobutanoyl chloride in the presence of pyridine to provide acylation of the secondary and primary hydroxyl sites within the glucose. The primary haloalkane sites of the intermediate tetra-ester were then subjected to displacement using the parent lipid 4-hexadecyl-1-aza-4-azoniabicyclo [2.2.2] octyl chloride.

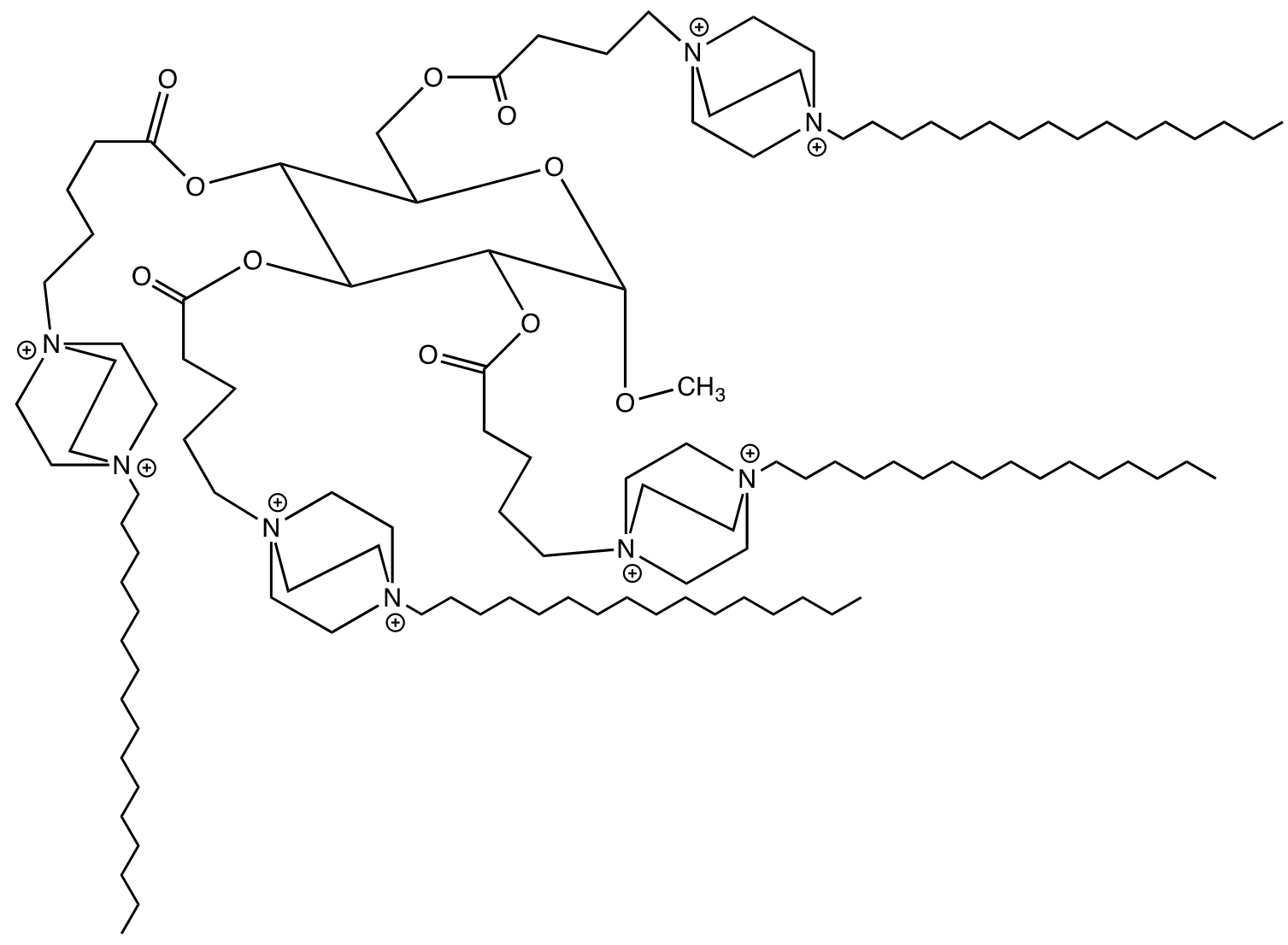

Investigations of II with Staphalococcus aureus and Escherichia coli exhibited values for $\mathrm{MBC}$ of $7.85 \mu \mathrm{M}$ and $19.6 \mu \mathrm{M}$ respectively, with MIC of $7.85 \mu \mathrm{M}$ and $19.6 \mu \mathrm{M}$ respectively. These values are significantly lower than those noted for $\mathbf{I}$,
II

indicative of a more favorable entropic factor involving several cationic lipid sites being brought into action against a bacterium simultaneously by a particular molecule of agent. 


\subsection{A PERSUBSTITUTED} CYCLODEXTRIN CATIONIC LIPID DERIVATIVE (III)

The material III was synthesized starting with $\beta$-cyclodextrin that was pertosylated according to a previously reported procedure. ${ }^{21,22}$ Each tosylated site was then subjected to displacement with a parent cationic lipid, 4-hexadecyl-1-aza-4azoniabicyclo[2.2.2] octyl chloride. The product was subjected to anion exchange to isolate the material as the chloride salt.

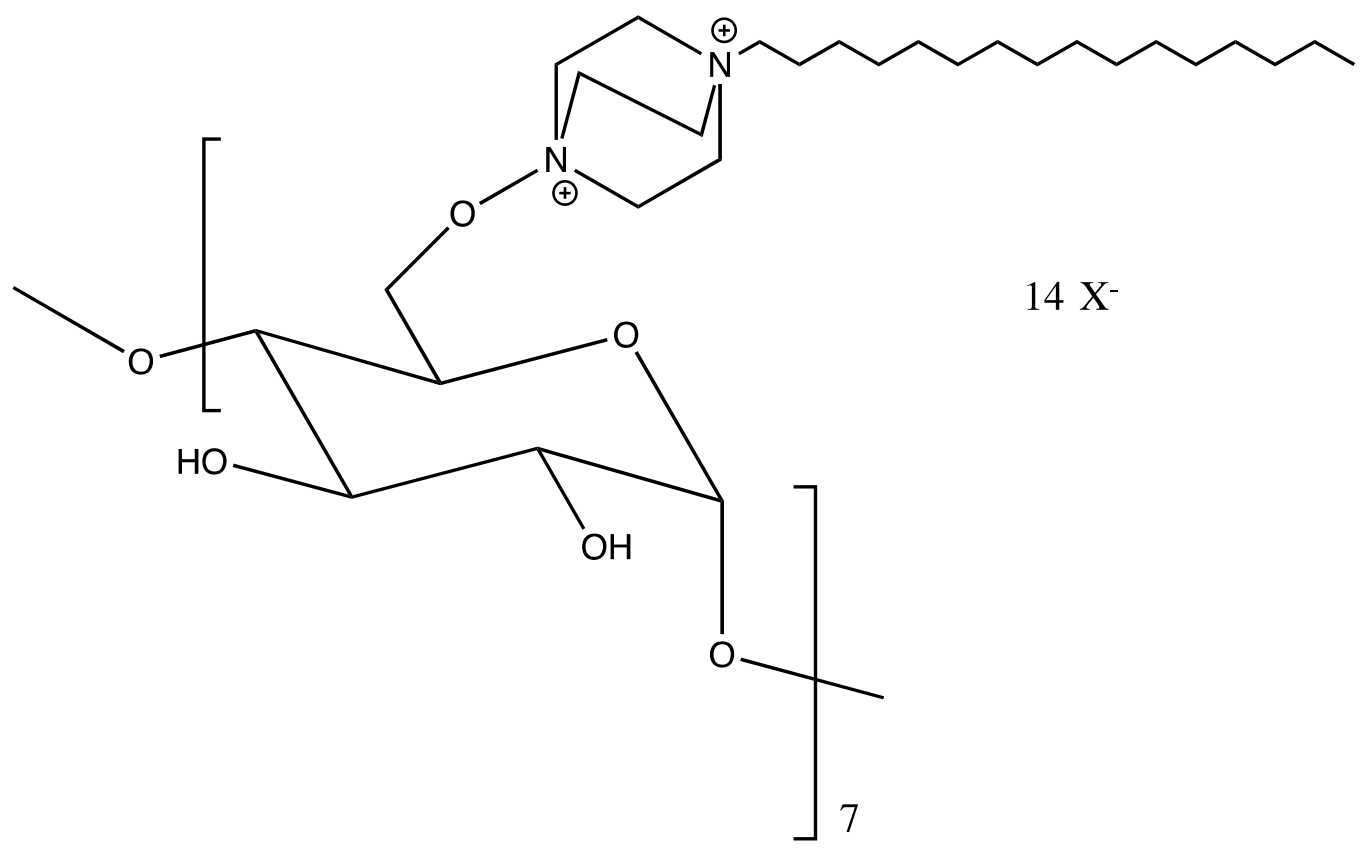

Investigations of III with Staphalococcus aureus and Escherichia coli exhibited values for MBC of $5.18 \mu \mathrm{M}$ and $10.4 \mu \mathrm{M}$ respectively, with MIC of $5.18 \mu \mathrm{M}$ and $10.4 \mu \mathrm{M}$ respectively. Again, with the arrangement of seven cationic lipid sites being brought into action simultaneously against a surface of a particular bacterium a more favorable entropic factor for activity is seen than with individual cationic lipid species.
III

\section{SUMMARY OF BIOLOGICAL RESULTS AND DISCUSSION}

The antibacterial efficacy of the synthesized polycationic agents are summarized in Table 1. Minimum inhibition concentrations (MIC) and minimum bactericidal concentrations (MBC) are shown in micromolar units for activity against representative Gram + and Gram bacteria (S. aureus and E. coli.). 
Table 1

\begin{tabular}{|c|c|c|c|c|}
\hline Compound & \multicolumn{4}{|c|}{ Activity } \\
\hline & \multicolumn{2}{|c|}{ S. aureus } & \multicolumn{2}{c|}{ E. coli } \\
\hline \multirow{2}{*}{} & MIC & MBC & MIC & MBC \\
& $\mu \mathrm{M}$ & $\mu \mathrm{M}$ & $\mu \mathrm{M}$ & $\mu \mathrm{M}$ \\
\hline I & 1274 & 254800 & 318.5 & 1275 \\
\hline II & 7.85 & 7.85 & 19.6 & 19.6 \\
\hline III & 5.18 & 5.18 & 10.4 & 10.4 \\
\hline
\end{tabular}

Clearly, the agglomeration of cationic lipid sites within a restricted space provides a favored antibacterial environment. This is seen to correlate with prior results of this laboratory ${ }^{20}$ in which were reported the in vitro antibacterial activity of similarly appended (with cationic lipid units) starch materials. The ultimate utility of such materials is certainly dependent on the in vivo deletion of these materials once activity toward the pathogenic bacteria has been utilized. We continue to search for scaffoldings (proteinaceous as well as carbohydrate) for the cationic lipids that will provide such clusters of active sites as well as be capable of deletion from the organism once desired activity has been accomplished.

\section{CONCLUSIONS}

AND

\section{OUTLOOK}

The concept of using cationic lipids associated with scaffoldings that allow multiple interactions with invasive bacteria that does not permit the development of mutant drug-resistant bacteria appears to be viable. The construction of such agents for treatment of pathogenic bacterial infection is within reach. It is necessary in the design of such agents to provide sufficient cationic lipid sites within a small molecule to allow multiple piercings of the bacterial surface so that the cell is destroyed.

Our particular efforts to date have been concerned with scaffoldings that involve carbohydrate units. Of particular significance are those related to the cyclodextrins as well as soluble forms of starch. It is necessary not only that sufficient sites be available such that contact of a single unit of the agent accomplishes the destruction of a bacterial cell, but also that the units of the agent be constructed such that the unit can be removed from the organism without detrimental side-effects once the mission has been accomplished.

In addition to continuing the investigation of carbohydrate related scaffoldings, we are looking to the use of proteinaceous units for the delivery of the cationic lipid species. Of particular interest is the use of oligomers of serine, with which cationic lipids can be attached through the modification of the primary hydroxyl site. In addition, proteinaceous-like oligomers can be generated with cationic lipid pendant units using normal synthetic methods for amino acids. These scaffoldings can provide both the concentrated array of cationic lipids suitable for bacterial cell destruction while also being degradable to disposable amino 
acid units once the bacterial cell destruction is complete.

\section{EXPERIMENTAL}

\section{1 GENERAL SYNTHETIC}

All reactants and solvents used in the syntheses and purifications of new materials were of commercial reagent quality and used without further purification. For all newly synthesized materials confirming ${ }^{1} \mathrm{H}$ and ${ }^{13} \mathrm{C}$ NMR spectra were measured with the samples dissolved in commercial deuterated solvents $\left(\mathrm{D}_{2} \mathrm{O}\right)$ using a Brüker $400-\mathrm{MHz}$ DPX400 instrument and satisfactory elemental analyses were performed by Columbia Analytics of Tucson, AZ. Procedures for tosylation and displacement of the tosylate units by the 4-alkyl-1-aza-4azoniabicyclo[2.2.2] octyl chloride species have previously been described in detail. ${ }^{10,20}$

\subsection{ANTIBACTERIAL DETERMINATIONS}

Samples were prepared in TSB (Tryptic Soy Broth) to the desired stock concentration. Ten tubes each with $1 \mathrm{~mL}$ of TSB were prepared and $1 \mathrm{~mL}$ of the sample in the stock solution was added to the first tube and mixed. Serial dilutions of the first tube were performed to the second and further tubes through the entire set.

Bacteria inoculum was prepared by suspending 4-5 colonies of the culture to be tested in $5 \mathrm{~mL}$ of TSB. Then, $100 \mu \mathrm{L}$ of the suspension was transferred to $25 \mathrm{~mL}$ of TSB and the mixture was agitated to ensure even distribution. Then, $1 \mathrm{~mL}$ of diluted bacterial culture was added to each of the dilution tubes and all tubes were subsequently incubated at $37^{\circ} \mathrm{C}$ for 24 hours. Tubes were then observed for growth (turbidity) and MIC concentrations calculated.

For determination of $\mathrm{MBC}$, ten tubes each with $1 \mathrm{~mL}$ of TSB were prepared and $10 \mu \mathrm{L}$ of each MIC solution was placed into the corresponding $\mathrm{MBC}$ tube. Tubes were incubated at $37^{\circ} \mathrm{C}$ for 24 hours and observed for growth (turbidity) and MBC concentrations were calculated.

\section{ACKNOWLEDGEMENTS}

The authors wish to thank the PSCBHE Research Award Program for financial support of this effort, and Prof. Mary Cloninger (Montana State University) for assistance in preparing the manuscript. 
Medical Research Archives, Vol. 5, Issue 3, March 2017

Polycations. XXIV. Approaches to Polycationic Alternatives to Antibiotics

\section{REFERENCES}

1. Spellberg B, Guidos R, Gilbert D, Bradley J, Boucher HW, Scheld WM, Bartlett JG, and Edwards Jr. J. The epidemic of Antibiotic-Resistant Infections: A Call to Action for the Medical community from the Infectious Diseases Society of America. Clinical Infectious Diseases 2008; 46:155-264. http://dx.doi.org/10.1086/524891

2. Human Microbiome Project Defines Normal Bacterial Makeup of the Body; National Institutes of Health (NIH), (2012). https://www.nih.gov/news-events/newsreleases/nih-human-microbiome-projectdefines-normal-bacterial-makeup-body

3. McDonnell G, and Russell, AD. Antiseptics and Disinfectants: Activity, Action, and Resistance. Clin. Microbiol. Rev. 1999;12(1):147-179. https://www.ncbi.nlm.nih.gov/pmc/articles/ PMC88911/

4. Antimicrobial Resistance: Global Report on Surveillance; World Health Organization: $\quad$ France, 2014. http://www.who.int/drugresistance/docume nts/surveillancereport/en/

5. Magiorakos AP, Srinivasan A, Carey RB, Carmeli Y, Falagas ME, Giske CG, Harbarth S, Hindler JF, Kahlmeter G, Olsson-Liljequist B, Paterson DL, Rice LB, Stelling J, Struelens MJ, Vatopoulos A, Weber JT, and Monnet DL. MultidrugResistant, Extensively Drug-Resistant and Pandrug Resistant Bacteria: an International Expert Proposal for Interim Standard Definitions for Acquired Resistance. Clin. Microbiol. Infect. 2012;18(3):268-281. https://www.ncbi.nlm.nih.gov/pubmed/217 $\underline{93988}$

6. Boucher HW, Talbot GH, Bradley JS, Edwards Jr. JE, Gilbert D, Rice LB, Scheld M, Spellberg B, and Bartlett J. Bad Bugs, No Drugs: No ESKAPE! An Update from

Copyright 2017 KEI Journals. All Rights Reserved the Infectious Diseases Society of America. Clin. Infect. Dis. 2009;48(1):1-12. https://www.ncbi.nlm.nih.gov/pubmed/190 $\underline{35777}$

7. Gilbert DN, Guidos RJ, Boucher HW, Talbot GH, Spellberg B, Edwards Jr. JE, Scheld WM, Bradley JS, and Bartlett JG. The 10 x '20 Initiative: Pursuing a Global Commitment to Develop 10 New Antibacterial Drugs by 2020. Clin. Infect. Dis. 2010;50(8):1081-1083. http://cid.oxfordjournals.org/content/50/8/1 $\underline{081 . f u l l}$

8. Appelbaum PC, 2012 and Beyond: Potential for the Start of a Second PreAntibiotic Era? J. Antimicrob. Chemother. 2012;67(9):2062-2068.

https://www.ncbi.nlm.nih.gov/pubmed/226 $\underline{87888}$

9. VanKoten HW, Dlakic WM, Engel R, and Cloninger MJ. Synthesis and Biological Activity of Highly Cationic Dendrimer Antibiotics. Mol.Pharmaceutics. 2016. https://www.ncbi.nlm.nih.gov/pubmed/276 61609

10. Abel T, Cohen JI, Engel R, Filshtinskaya M, Melkonian A, and Melkonian K. Preparation and Investigation of Antibacterial Carbohydrate-Based Surfaces. Carbohydrate Research. 2002;337:2495-2499. http://dx.doi.org/ $\underline{10.1016 / \mathrm{S} 0008-6215(02) 00316-6}$

11. Cohen JI, Abel T, Burkett D, Engel R, Escalera, J. Filshtinskaya M, Hatchett R, Leto M, Melgar Y, and Melkonian K., Polycations. 15. Polyammonium Surfaces A New Approach to Antifungal Activity. Letters in Drug Design \& Discovery. 2004;1:88-90. http://dx.doi.org/102174/ $\underline{1570180043485752}$

12. Engel R, Cohen JI, and Fincher, KM. Antimicrobial Surfaces. (2007) US Patent 
Medical Research Archives, Vol. 5, Issue 3, March 2017

Polycations. XXIV. Approaches to Polycationic Alternatives to Antibiotics

7,241,453. https://www.google.com/ patents/US7241453

13. Engel R, Cohen JI, and Fincher KM. Antimicrobial Surfaces. (2007) US Patent $7,285,286$. http://www.google.ch/ patents/US7285286

14. Engel R, Rizzo JI, and Fincher KM. Antimicrobial Surfaces. (2012) Canadian Patent 2,481,199. http://www.ic.gc.ca/opiccipo/cpd/eng/patent/2481199/summary.htm 1?query $=(($ Antimicrobial + Surfaces $)+\% 3 \mathrm{CI}$ N\%3E+TITLE) $\% 3 \mathrm{CAND} \% 3 \mathrm{E}+(\mathrm{US}+\% 3$ CIN\%3E+INVTCOUNTRY)\&start=1\&nu $\underline{\mathrm{m}=50 \& \text { type=advanced_search }}$

15. Engel R, Rizzo JI, Fincher, KM, and Innocenti G. Embedding Antibiotic Compounds in Solid Polymers. (2013) US Patent 8,470,351. https://www.google.com/ patents/US8470351

16. Urban C. (2011) Private Communication. New York Hospital Queens, Flushing, NY.

17. Calomiris JJ. (2005) Private Communication. Aberdeen proving grounds, Aberdeen, MD.

18. Calomiris JJ. (2005) Inactivation of the Bacillus anthracis Spore on Fabric Amended with a Quaternary Ammonium Compound. Paper presented at the American Society for Microbiology,
Biodefense Research Meeting, Baltimore, MD, $22 \quad$ March 2005. http://www.scirp.org/(S(351jmbntvnsjt1aad kposzje))/reference/ReferencesPapers.aspx? $\underline{\text { ReferenceID }=1850621}$

19. Ragolia L. (2010) Private Communication. Winthrop University Hospital, Mineola, NY.

20. Engel R, Ghani I, Montenegro D, Thomas M, Klaritch-Vrana B, Castaño A, Friedman L, Rothman, L, Lewe H, Capodiferro C, Ambinder D, Cere E, Awad C, Sheikh F, Rizzo J, Nesbitt L-M, Testani E, and Melkonian K. Polycationic Glycosides. Molecules. 2011;16:15081518.

http://doi:10.3390/molecules16021508.

21. Cramer F, Mackensen G, and Kensse K. Über Einschlussverbindungen, XX. ORD-Spektren und Konformation der Glucose-Einhalten in Cyclodextrinen. Chem. Ber. 1969;102;494-508 http://doi/10.1002/cber.19691020217

22. Cohen JI, Castro S, Han J, Behaj V, and Engel R. Polycations. IX. Polyammonium Derivatives of Cyclodextrins: Syntheses and Binding to Organic Oxyanions. Heteroatom. Chem. 2000;11;546-555 http://doi/10.1002/10981071(2000)11:7<546::AID-

$\underline{\mathrm{HC} 14>3.0 . \mathrm{CO} ; 2-\mathrm{R}}$ 